\title{
Civilian Trend in the Australian Literature as a Resource of National Moral Values
}

\author{
Elena B. Grishaeva* \\ Siberian Federal University \\ 79 Svobodny, Krasnoyarsk, 660041, Russia
}

Received 01.02.2017, received in revised form 18.12.2017, accepted 15.01.2018

The article takes issue with a particular chronological period of development of the Australian literature - the turn of the $19^{\text {th }}-20^{\text {th }}$ centuries. Beginning with formal description of its civilian stream, the paper features a combination of major values and core imprints under a steady attention of iconic authors towards everyday life of the pioneers of the nation, their hard work and desire to explore vast lands, and as a result, to build a strong state. Under the scope of a closer attention is the concept "mate-mateship" related to the up-country labourers, shearers and shed-hands, which allows for applying a panchronic approach. On the synchronic side, the focus is on the bright and contributive efforts of a plethora of authors, while on the diachronic side the emphasis is on the moral features and traditional values, which remain of utmost importance for Australians.

Keywords: Australian literature, national identity, mateship, loyalty, friendship.

DOI: 10.17516/1997-1370-0206.

Research area: philology, culturology.

"I love a Sunburnt Country"

(Dorothy McKellar 1885-1968)

\section{Introduction}

Though Australia is a young country, it has come a long way from the British resettlement colony through a dominion to a sovereign state. While talking about the Australian heterogeneous ethnic and cultural society, one should think of the roots of its spiritual culture as well as about the values. Comprehensive approach to both cultural and linguistic factors always comes into play in the context when there is a need to show a person as a reflector and specifier of the conceptual world of the ethos in question together with its language and culture.

Human activity determines raisons d'être of the nation. The aim of the paper is to show the Australian value system formation via major literary topical themes in the Australian authors' literary heritage of the national epoch. Thus, moral values and their meanings traditionally were under the scope of wider examination of literary critics, sociologists of language and readers. In spite of the breadth and depth of the literature on these particular issues, a few attempts have been

(C) Siberian Federal University. All rights reserved

* Corresponding author E-mail address: e-grishaeva@mail.ru; elena.grishaeva2@mail.ru 
made to expose through the lenses of language, social discourse of creative works and cultural background of communicative live and literary environment that reflects the concept sphere of the Australian nation.

A two hundred year history of the Australian literature elucidates three distinctive periods of its development and growth:

1. Colonial (Anglo-Australian epoch (1788-1880);

2. National epoch (1880-1920);

3. Contemporary epoch (1920 - until now).

As it is habitually considered, the narrative art of Australian authors since the end of the $18^{\text {th }}$ century has encapsulated the character of a new continent into literature, discovering a plethora of multi-faceted issues: aboriginality, mateship, national identity, migration, Australia's unique location and geography and the "beauty and the terror" of life in the Australian bush, a landscape that is alive but also threatening and alienating.

Internationally renowned classic writers of the national era include Banjo Paterson, Henry Lawson, C.J. Dennis, Dorothea Mackellar, K.S. Prichard and many others.

Australian language, letters and literature have been influenced by Aboriginal storytelling, convict tales and the desire of colonists to relate to their experiences in a new country.

Some of those early works have remained part of the Australian ethos. Marcus Clarke's "For the term of his natural life" is still being published nowadays.

"The Bulletin", a weekly almanac started the national epoch of the Australian literature. John Hynes and Jules François Archibald, a leading figure at the Bulletin Magazine and a long-time supporter of H. Lawson, pioneered the programmed principles of the miscellany: social engagement, radical democratism, interest in the low class workers' life and reluctance to acknowledge the British influence on the
Australian literature. "The Bulletin" was known as the "bushman's bible" - required reading for direction as to how one should live one's life..." (Bryan, 2016: 17). The magazine carried forward such topical issues as life in the bush, rural ideals, male friendship and mateship, equal opportunities for everyone.

Andrew Barton Paterson, a poet and a balladeer, became popular just after he had published his first poems about the Australian bush in 1885 . He chose for himself his pen name Banjo (the pseudonym was related to his favorite horse's nickname). Having been a nationalistically minded personality, he had published in 1889 his poignant pamphlet "Australia for the Australians" which echoed, on the one hand, his deep disdain for the chip labour force and, on the other hand, his admiration with the Australian national spirit.

A.B. Paterson turned to be a symbolic and productive author, steadily publishing his famous creative works: "The Man from Snowy River" (1890), "Clancy of the Overflow" and a book of his poems (1895). Due to A.B. Paterson's contribution, the Australian national poetry received a label "The Bush Poetry". Amongst the main literary characters were farmers, hunters and rural workers. He created what is probably the most famous Australian verse, "Waltzing Matilda", which is still regarded as an informal anthem of Australia.

Another symbol of the civilian poetry is a flamboyant author Henry Lawson (1867-1922), arguably the most recognizable name in all Australian literature. Some of his poems appeared above the nom de plume, Tally - a reference to a shearer's tally of the number of sheep shorn in a day. Other pseudonyms employed by Lawson throughout his career included Cervus Wright, Youth, Caliban, HAL (Henry Archibald Lawson), Joe Swallow, Rumfellow, and Jack Cornstalk.

B. Paterson and H. Lawson clashed in the famous "Bulletin Debates" over the nature of 
life in Australia. Lawson said Paterson was a romantic and Paterson said Lawson was full of doom and gloom (Archived copy, 2011).

The iconic Australian author, Katharine Susannah Prichard (1884-1969), pioneered first socially centred novels. She wrote "Black Opal" (1921) and "Working Bullocks" (1926), claiming the right of her fellow-citizens for decent life and happiness. She was featuring the Australian working class realistically strengthening the routine life and concerns of the labourers. She managed to shape her social attitude towards lower social classes in Australia and chanted their strong and high-spirited character.

K.S. Prichard used to emphasise that she always loved labourers; she liked to conversate with drovers and working bullocks, woodsmen, gold diggers, miners, fishers, pearl divers, cattlemen, season workers, farmers, fruit-growers and teachers. All those characters carried a name of pioneers - people living a tough life, painstakingly working, taking off the Bush soil patches, which could feed them and their families.

John Morrison dedicated his short story "Pioneers" to the first generation of farmers. He published his short stories under the titles "Sailors Belong Ships" (1947), "The Black cargo" (1955), "Overland Winter-Spring" (1960). His novels "The Creeping City" (1949) and "Port of Call" (1950) were full of social contrasts and portrayed behavioural patterns, moral and ethics of contemporary people.

Vance Palmer (1885-1959) was famous for his democratic alienation. His outstanding novels "The Outpost" (1924), "The Man Hamilton" (1928), "The Passage" (1930) showed the destiny of the Australian working people and the history of the working movement in Australia. Many his literary works mirrored the spirit of proletarian solidarity and rooted the national playwriting.

Donald Stuart was born in Western Australia. He started his career at the age of 14 as a swagman, an itinerant who wandered the roads seeking casual work.

Literary critic Professor Adam Shoemaker wrote: "Donald Stuart, probably comes the closest of any White Australian writer during this period to a sensitive depiction of the Aboriginal people as Aboriginal human beings" (Shoemaker, 1992).

The names of early Australian poets and novelists are well known today. It would be next to impossible to make a full list of their stunning names. They conjure images of a time of exploration, adventure and excitement, as well as a poignant reminder of the hardships of living in newly formed colonies.

\section{Problem Statement}

As it is widely emphasised, modern Australian poets were largely influenced both by the "literary nationalism" of the late 1890 s which espoused Australian values as well as the contemporary modernist writings which challenged writers to use their imagination and be innovative in describing what was "real". Coming back in the days, it is a must to address the legacy of the giant, one of the most solemn and influential Australian poet of the epoch, Henry Lawson.

He became known for his socialist and patriotic writing: he supported unionism and commented on local politics. He wrote his poems as marching songs full of revolutionary pathos, enthusiasm, socialist ideas and social optimism. $\mathrm{He}$ declared his revolutionary rigour along with national and patriotic motives. His realistic poems in the book "In the Days When the World was Wide", "Other Verses" (1896) and "When I Was King" (1905) were popular with Australian labourers.

H. Lawson thoroughly described his main hero - a mate, pointing out in details his character, appearance, value standpoints which had influenced the formation of the Australian 
national features and a system of moral values back in the days. Thus, Lawson recorded Australia's past and shaped her future.

It is suffice to remind Alexander Harris' emphasis on habits of mutual helpfulness between mates: they "stand by one another through thick and thin; in fact it is a universal feeling that a man ought to be able to trust his own mate in anything" (Seal, 1989: 50).

In Australian classic literature, the term "Mateship" denoted "an intensely loyal relationship of shared experience, mutual respect and unconditional assistance existing between friends (mates) in Australia" (Australian literature). It is worth mentioning that this type of relationship of male loyalty has remained a core subject of Australian Literature from colonial times to the present day.

Henry Lawson echoed in his work "A Sketch of Mateship and Shearers":

They tramp in mateship side by side -

The Protestant and Roman

They call no biped lord or sir

And touch their hat to no man (Seal, 1989: 50).

\section{Discussion}

Henry Lawson was born to the family of the Norwegian sailor, the immigrant, who had arrived in Australia in the middle of the $19^{\text {th }}$ century due to "the gold rushes". Gold had been found in Australia by a convict at Bathurst in 1823 (Moore, 2008: 78). At the beginning of his career H. Lawson was a decorator, a clerk and a teacher for Maori students in New Zealand. One of his trades was house-painting at the Great Western Hotel when he was living in Burke, the metropolis of the Great Scrubs, on the banks of the Darling River, about five hundred miles from Sydney. As a poet and author, he had the harder edged view of the Bush featuring a severe life of hard working Australians, writing simple stories of gold diggers, coal-miners, farmers and cattle drovers. His realistic novels are the national and literary legacy of Australian nation. All the novels derive from a short oral story, anecdote or tale. His short stories spring from the culture of yarn where the plots were endlessly woven and intertwined whimsically with reality. Eyewitness' or an event spectators' lyrical story is harmonious and organic. It perfectly fits in entire unity of the author and his characters. Many stories and legends originate in the outback, in the drovers and squatters and people of the barren, dusty plains (Seal, 1989: 50).

Henry Lawson's literary works feature epos of the forming Australian nation. The author found basics in ethics, morale and values that turned to unify Australian society. "Australia! My country! Her very name is music to me. God bless Australia”, he enthused at one time. He also chanted the Australian worker, the miner rushed to Western Australia, "the exciting prospects of the dawn of the twentieth century, the patriotism and confidence of Federation..." (Bryan, 2016: 14). H. Lawson framed an image of the heroes the mates - the pioneers of the nation. He always kept in mind once written words "The Men Who Made Australia". "The men who made the land, who conquered deserts, with whom he could share a beer, the hard-working, hard-drinking men he had come to idealise and they were welcoming him into their group" (Bryan, 2016: 81-82).

Dramatic and severe circumstances of the Australian history made possible the development of national literary genre back in the days. Due to democratism as one of the important features of the novel, civilian literary and dramaturgic trend holds a naïve and confidential intonation, bridging the teller and his listeners, rural workers, swagmen, who were looking for seasonal jobs and having a sack of all their belongings at their back.

A bit later, this image of the main character has changed. The bush became their home and cradle. Outback of Australia swallowed Bushmen, 
who were dragging along the sandy roads for many days, when it was hot or vice versa, when it was raining, and dreary weather drove every one crazy. They drifted from one state to another. They slept on the ground and got warm near the fire and their mates.

Thus, the pioneers of the bush literature portrayed the Australian character of the hardworking men: sheepshearers wandering from one farm to another and gold diggers turning mad about golden rushes. Farming was also a disaster under drastic climatic conditions. Farmers never knew the result, whether the harvest would be good or not. They endlessly put their efforts into ground handling. Either hot weather or heavy rains caused losses and devastated lands.

It is not an exaggeration that $\mathrm{H}$. Lawson was indeed the voice of Australia, proclaiming far and wide the ideal, which, in the simple dialect of the bush, is called "Mate-iness" (Bryan, 2016: 381). These were the declaration of the Governor, Sir Philip Game, on 28 July 1931 in the Domain area of Sydney during the emplacement of the bronze statue nine years after Lawson's death. He was a poet, storywriter and a mate to all men.

H. Lawson, once separated for a quarter of a century from his dearest friend, Jim Gordon, published a postscript to the sketch "In a Dry Season" where he wrote: "Never tackle the bush without a good mate. With one you can do anything and go anywhere" (Bryan, 2016: 173). J. Gordon, in his turn, wrote of his mate H. Lawson: "A loyal mate. A true comrade. He love the bush and its people and they, in turn, through his work learned to know and to love and honour him and even to this day, amongst them, from the Gulf to the Bight, from Broom to Brisbane, his name is a household word" (Bryan, 2016: 177).

Even decades after Lawson's death, J. Gordon thought often of him and missed his companionship dreadfully. "A giant friend, a staunch and loyal mate, a lover of little children, a courteous gentleman with women and a tender champion of right and justice. Such a man was my friend Henry Lawson. Such was Henry Lawson as I knew him. May his restless spirit have found sanctuary" (Bryan, 2016: 397).

From the point of view of lingva-cultural approach and cognitive linguistics, one can assert that creative woks of Australian authors were displaying a so called "author's concept" "MateMateship" assuming conceptual, descriptive and axiological constituencies. The core of the conceptual background includes divergent lexeme, borrowed from the British English. As for the descriptive constituent part, it was formed referring to the individual understanding of the particular author. Thus, the image and axiological components, resulting and reflecting lifestyle in the particular cultural and historical settings, were associated with a main hero, who was a close to the bone hooligan, Jack-of-all-trades, a swagman, and finally, a hard-working fellow.

Australian cultural core values in the historical perspective represent a dynamic model of a particular axiological cultural and linguistic paradigm. This paradigm reflects a national Australian concept sphere.

Australians as a nation and representatives of other countries and cultures perceive stereotypically a concept "Mate-Mateship" as a major imprint. When someone needs to emphasise such intrinsic Australian features and qualities as reliability, spirituality, persistence, sustaining power, courage and readiness to help, he uses these terms metaphorically. Scholars often argue, "Perhaps born out from the cruel hardships of convict life or the working class egalitarianism of British society, mateship embodies equality, loyalty, and friendship" (The American Individual..., 2012).

It is a well-known fact that in her 2011 Australia Day speech, the former Prime Minister 
Julia Gillard said that "mateship defines the spirit of Australia" (The American Individual..., 2012). The concept is so central to Australian identity that there were intentions to include this concept into the preamble of the Australian Constitution during the 1999 Constitutional referendum.

Glenn Davis, a historian, wrote: "As Aussies we recognise that individual achievement rarely occurs without a helping hand from others. We value independence in a community minded way. Despite our difference, we all know that when adversity strikes, whether in the form of bushfires, floods or international conflict, there'll be a fellow Aussie to help out. It is the tradition of a digger, the character of mateship and it's still the essence of the Australian spirit" (The American Individual..., 2012).

The period of formation of the Australian literature evidences some parallels with forms of nationalism at the end of the $19^{\text {th }}$ century. "Nationalism was also the voice of the writers and artists of the period... looking to the glory and pride in assured nationhood" (Moore, 2008: 103).

At the first Federation conference in 1890 Henry Parkes asserted: "Make yourself a united people... We should create an Australian home... We should have home within our shore" (Official Record..., 1890: 225). There was much intermingling of cultural, political and literary circles back in time.

"The Bulletin" promoted Australian English and fostered writers who used a distinctively Australian idiom. It meant that the interest in Australian English was another manifestation of cultural nationalism. The writers seemed to be able to provide Australia with language that was Australian. H. Lawson was often described as "the first articulate voice of our nationhood - the one who helped Australians to look at themselves, recognizing a unique people, and to be proud of who and what they saw" (Bryan, 2016: 15).
B. Moore claims that "unlike the American political and linguistic rebellion resulted in Noah Webster's changes to the spelling system, Australian nationalism was still very much tied to notions of Empire". (Moore, 2008: 104). The linguist argues, "Shifts in the meaning of standard English words - mate is a good example - reflected Australian social values that differed from the British. Many of the senses of mate are shared with other Englishes, but it is the specialized sense, 'one with whom the bonds of close friendship are acknowledged, a "sworn friend", that is distinctive. This is the quintessential Australian sense, a sense that does not exist in other Englishes. The first citation in AND (Australian National Dictionary) is from 1891: "Where his mate was his sworn friend through good and evil report. In sickness and in health, in poverty and plenty, where his horse was his comrade, and his dog his companion, the bushman lived the life he loved" (Hales, 1891: IV). The final citation in AND, from 1986, continues this tone: "Silence was the essence of traditional mateship... The gaunt man stands at his wife's funeral; his mate comes up, says nothing but rests a gentle hand briefly on his shoulder" (Bulletin, 1986: 36).

A. Moore highlights that "In human contexts, the noun mateship is exclusively Australasian. It means "the bond between equal partners or close friends; comradeship; comradeship as an ideal". ...Its widespread usage occurs in the 1890s: "Real mateship! It is what the lowly Nazarene taught. But it will never be learnt so long as we are more jealous of our own reputation than anxious for the welfare of our fellows" (Worker, 1894: 3). It gathers to itself notions of egalitarianism, the rejection of class structures, and the rejection of the trappings of social status, as Henry Lawson would stress in "Shearers" (1901):

They tramp in mateship side by side -

The Protestant and Roman 
They call no biped lord or sir

And touch their hat to no man" (Cited: Moore, 2008: 104-105).

Unfortunately, H. Lawson became addicted. His alcoholism enfolded him in the final decade of his life. Using one biographer terms H. Lawson was reduced to living: "a pitiful travesty of life... to shameless begging" (Bryan, 2016: 3). He himself, being aware of his disease, dreamt to repeat his twenties:

The twenties they were noble,

The bravest years, I think;

"Twas man to man in trouble,

In working and in drink; (Cited: Moore, 2008: 104-105).

In his "When I Was King" book he thinks about his outback Bourke mates:

And they were men in spite of all, and they were straight, and they were true...

$$
<\ldots>
$$

I know they drank, and fought, and died some fighting fiends on blazing tracks -

I don't remember that they lied, or crawled behind each other's backs;

I don't remember that they loafed, or left a mate to battle through -

Ah! Men knew how to stick to men in Ninety-one and Ninety-two (Bryan, 2016: 5).

Lawson's biographers used to say of him that he was "the apostle and prophet of the gospel of mateship" and he "preached his wonderful gospel of brotherhood" (Bryan, 2016: 17). This stigma attests a point of view that much of Australian ethos of mateship was developed in the writings of H. Lawson. Denton Prout, Lawson's bibliographer, claimed that in the rough and dangerous interior country, a mate was a necessity. As H. Lawson himself wrote, the mateship of the bush was

"born of barren lands,

Of toil and thirst and danger"; and the kindness these men extended to one another were a product of "shared hardship, drought and homelessness" (Bryan, 2016: 87). Through him, mateship converted to "the watchword of Australia", a prerequisite of national identity (Bryan, 2016: 17). In a tough place, one simply increased his chances of survival by enlisting the aid of another who would watch out for him.

Surprisingly, but there were days when H. Lawson seemed to destroy his idols and shatter his dreams. He found to have little in common with whom he worked with. He could quickly come to hate his companions, his surroundings, his job, and his life. He started mocking of those who had romantic views of the bush worker. The reality was different: unthinkable adjectives and adverbs, ... worse words for the boss over the board - behind his back, ... non-stop flow of vulgar language" (Bryan, 2016: 109). His dreams of noble unionists with admirable union ideals still flickered through his mind and inspired his heart. In that period Lawson's moods changed from excitement and optimism to doom and gloom. One day the bush was paradise while the next it was hell on earth.

Lawson's reflections evidenced his disillusionment: he resigned himself to a trapped existence in the bush. He once wrote:

"I am a rouseabout of the rouseabouts...I had that ambition once, when I was the softest of green hands; ... I've got used to hell since then. ... I was never much of a liar..." (Bryan, 2016: 118).

Gradually, Lawson realised that the former image bad been nothing but an idealised but entirely ignorant and impractical one. He wrote: "I lost faith in human nature!". Then he goes on to say, "Comrade." No! I hate that word now. It has become a word of cant like "Brother", and "Union" - like your "Mateship!" I am disgusted with it all" (Bryan, 2016: 123). 
At the same time, his eager eyes searched for "copy" for his stories and poems. His Brisbane Boomerang companion, A.G. Stephens wrote, "It is because he feels so deeply that he writes so strongly" (Bryan, 2016: 110). Lawson's colleague, a writer and a journalist, R.J. Cassidy eulogized in the Australian Worker newspaper days after his death: "Yes, Henry Lawson is dead, but his name and his fame will live on, and grow greater as the years pass by; for he was a Poet of the People, a teller of their tales, and an inspired interpreter of their desires and dreams" (Bryan, 2016: 406).

At the end of the $19^{\text {th }}$ century - the beginning of the $20^{\text {th }}$ century $\mathrm{H}$. Lawson and T. Collins developed and deepened democratic and national literary traditions. The economic depression that struck Australia so hard during the early 1890s was spreading its gloom over the country. They were showing struggle for better life and people's protests against social unfairness. As B. Moore argued, "Fairness" is another central value that emerges at this time" (Moore, 2008: 105). "This is a land of the "fair go" (Moore, 2008: 106). In this context there should be mentioned such literary works as H. Lawson's "While the Billy Boils" (1896), "On the Track" (1900), "Over the Sliprails" (1900) and "Joe Wilson and his Mates" (1901). Joseph Furphy (aka Tom Collins) published on 1 August 1903 a novel "Such is Life" - a fictional account of rural dwellers, including bullock drivers, squatters and itinerant travelers. Ironically, "such is life" were Ned Kelly's last words which he said as he was about to be hanged. The book is a display of low characters and mundane events, teasing the reader with its tangents. Critique mentioned that realism had always been the great joy of the novel. The author sophisticatedly managed to capture the flavor of interaction between the bush dwellers, their vernacular they were using, the landscape and nomad's modus vivendi.

\section{Conclusion}

This paper briefly examined a short period of the Australian literature, which is meaningful for better understanding Australians as a nation and bearers of their national mentality and traditional values which are linguistically and culturally induced. Holistically speaking, literary works of the iconic writers had a precise impact on the policymaking process of the young nation, on the one hand. On the other hand, their stated principles and a national feature as "mateship" are being constantly accommodated and adjusted by every consecutive influx of immigrants, striving eagerly and struggling for the citizenship of Australia.

In this context, it is important to remember, that the names of many Australian authors, poets and writers of that time would never be forgotten. To conclude, I turn to a central dimension of any cultural process, namely that while this inherent reciprocal nature of intertwined past and future is being on the agenda of us, living today, there would not be a room for such a sad revelation as had been confessed by Jim Gordon who saw himself as "almost the last of a type that is passing" (Bryan, 2016: 398).

\section{References}

1901 manuscript in Mitchell Library. First published 1902.

Archived copy (2011). In Archived from the original on 8 April. Retrieved 2011-01-29.

Australian Literature, available at:

Australian Short Stories (1975). Moscow, Progress Publishers, 399 p.

Bulletin (Sydney) (1986). 21 January, p. 36. 
Bryan, G. (2016). Mates. The Friendship That Sustained Henry Lawson. London-SydneyAuckland, New Holland Publishers Pty Ltd, 2016, 488 p.

Hales, A.G. ('Smiler') (1891). The Wanderings of a Simple Child, $3^{\text {rd }}$ edn. Sydney, Runge \& Co., p. IV.

Moore, B. (2008). Speaking Our Language. The Story of Australian English. South Melbourne, Vic, Oxford University Press, 225 p.

Official Record of the Proceedings and Debates of the Australian Federation Conference (1890). Melbourne, Government Printer, p. 225.

Seal, G. (1989). The Hidden Culture: Folklore in Australian Society. Melbourne, Oxford University Press, $50 \mathrm{p}$.

Shoemaker, A. (1992). Black Words, White Page: Aboriginal Literature 1929-1988, Queensland, University of Queensland Press.

The American Individual and the Australian Mate (2012). In Cosette on June 25, available at: http://webarchive.nla.gov.au/gov/

Worker (Sydney) (1894). 22 December, p. 3.

\section{Гражданское направление в литературе \\ как источник формирования \\ нравственных ценностей австралийцев}

Е.Б. Гришаева

Сибирский федеральный университет

Россия, 660041, Красноярск, пр. Свободный, 79

Статья рассматривает нравственные и цеенностные смысль австралийской культуры через призму общности языка, социильного дискурса и культурного фона. Коммуникативное жизненное и литературное пространство, отражающее концептосферу австралийцев, оформилось под мошным влиянием корифеев австралийской прозы и поэзии на рубеже 19-20 вв. Литературные произведения национального периода символизируют особенности идентичности и национального характера австралийского народа. Лингвокультурный анализ индивидуальноавторской концептуальной пары “Mate-Mateship" выполнен на примере поэтических произведений Г. Лоусона.

Ключевые слова: литература Австралии, национальная идентичность, товарищество, лояльность, дружба.

Научная специальность: 10.00.00 - филологические науки, 24.00.00 - культурология. 